\title{
AUGMANTED REALITY PENGENALAN HEWAN PURBAKALA ANIMASI 3 DIMENSI DENGAN PATTERN RECOGNITION BERBASIS ANDROID
}

\author{
Alvebi Hopaliki $^{1)} ;$ Yupianti $^{2)}$; Juju Jumadi ${ }^{2)}$ \\ 1,2) Program Studi Informatika Faku/tas IImu Komputer Universitas Dehasen \\ Bengkulu \\ Email: ${ }^{1)}$ Alvebi48@gmail.com ;2) yupita@unived.ac.id
}

\section{How to Cite :}

AlvebiHopaliki ${ }^{1}$; Yupianti $^{2}$; ;ujuJumadi ${ }^{2}$, AUGMANTED REALITY PENGENALAN HEWAN PURBAKALA ANIMASI 3 DIMENSI DENGAN PATTERN RECOGNITION BERBASIS ANDROID. GATOTKACA Journal. DOI:https://doi.org/10.37638/gatotkaca.1.1.71-82

\section{ARTICLE HISTORY}

Received [12Januari 2020]

Revised [16 Februari 2020]

Accepted [20 Maret 2020]

\section{KEYWORDS}

This is an open access article under the $\underline{C C-B Y-S A}$ license

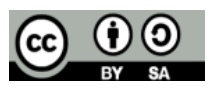

\section{ABSTRAK}

Augmented Reality (AR) adalah sebuah variasi darilingkungan virtual atau lebih sering teknologi AR pengguna dapat melihat dunia nyata, dengan objek-objek virtual yang ditambahkan ke dunia nyata. Jadi, pengguna melihat objek virtual dan objek nyata berada pada suatu tempat yang sama. Augmented reality membutuhkan video streaming dengan kamera yang digunakan sebagai sumber masukan gambar, kemudian melacakdan mendeteksi marker (penanda). Setelah marker terdeteksimaka akan muncul model 3D dari suatu barang. Model 3D inidibuat dengan menggunakan perangkat lunak untuk desain3D, misalnya 3DS Max, Blender dan lainlain.Pada media pembelajaran hewan purbakala ini menggunakan pengenalan pola (Pattern Recognition) yang dapat diartikan sebagai tindakan mengambil data mentah dan bertindak berdasarkan klasifikasi data.Maka dapat di ambil rumusan masalah Bagaimana merancang objek 3D dengan aplikasi Blender untuk pengenalan hewan purbakala. Tujuan pembuatan skripsi adalah untuk membangun media pembelajaran hewan purbakala secara real time dengan menggunakan teknologi augmented reality.

\section{ABSTRACT}

Augmented Reality (AR) is a variation of the virtual environment or more often calledasAR technology users that can see the real world, with virtual objects added to the real world. So, users see virtual objects and real objects are in the sum place. Augmented reality requires streaming video with a camera that is used as a sowce of image input, then tracking and detecting markers. After the $W$ is detected 30 model will appear of an item. This 3D model was mated mite software for 3D design, jbr example 3DS Max. Blender and others In this ancient animal leaming media using pattern recognition that can be interment! as taking raw data and based on data 
classification Then it can take the mutation problem how to
design 30 objects with the Blender application to introduce d
anc'ient animals. purpose of this $m$ is to build ancient animal
leaning media in real time by using augmented reality
technology.

\section{PENDAHULUAN}

Hewan purbakala atau yang sering disebut dinosaurus merupakan hewan yang hidup pada zaman prasejarah. Meskipun telah punah, pengetahuan mengenai binatang purba ini masih bisa dipelajari saat ini dari fosil hewan, buku, film dan berbagai media lainnya. Banyak media yang memberikan informasi mengenai pengetahuan binatang purba zaman prasejarah ini. Salah satunya buku ensiklopedia, tetapi media pembelajaran ini sifatnya tetap dan monoton karena berisi tulisan dan gambar, maka dari ituuntuk menarik minat belajar siswa mengenai hewan purbakala ketika belajar sejarah di sekolah setingkat SMP dan SMA yang hanya terdapat gambar berupa gambar fosil hewan purbakala yang ditemukan di beberapa tempat didunia tanpa diketahui bagaimana cara hewan tersebut berjalan, berlari, makan, atau bahkan ketika mereka mati.

Augmented Reality (AR) adalah sebuah variasi dari lingkungan virtual atau lebih sering teknologi AR pengguna dapat melihat dunia nyata, dengan objek-objek virtual yang ditambahkan ke dunia nyata. Jadi, pengguna melihat objek virtual dan objek nyata berada pada suatu tempat yang sama. Pada saat ini augmented reality semakin berkembang dan mulai banyak juga aplikasi maupun library yang digunakan untuk mengembangkan augmented reality Misalnya ARToolkit, Flartoolkit, Goblin, dan lainlain.

Realitas maya (virtual reality) merupakan teknologi yang membuat pengguna dapat berinteraksi dengan suatu lingkungan yang disimulasikan oleh komputer (computersimulated environment), suatu lingkungan sebenarnya yang ditiru atau suatu lingkungan baru yang terdapat dalam komputer. Dalam virtual reality, informasi mengenai dunia virtual yang ditampilkan ke indra pengguna dapat bersifat visual (paling umum) menggunakan layar atau head mounted display, audio menggunakan headphone, dan bahkan sentuhan menggunakan sarung tangan khusus.Namun, pada perkembangannya virtual reality memiliki cabang baru yang bahkan menyaingi virtual reality itu sendiri.

Dari kelebihannya tersebut, suatu benda yang sebelumnya hanya dapat dilihat secara 2D dapat muncul sebagai objek virtual yang dimasukkan ke dalam lingkungan nyata secara nyata dan memiliki banyak peluang untuk terus dikembangkan, tidak ketinggalan dalam bidang pendidikan sebagai media pembelajaran. Media pembelajaran yang dimaksud adalah media yang dapat menimbulkan rasa ketertarikan siswa untuk terfokus pada pembelajaran dan merangsang peran aktif siswa dalam menemukan, mengkonstruksi pengetahuannya sendiri.

\section{LANDASAN TEORI}

\section{Sejarah augmented reality}

Menurut putra (2013:ii-6) mendefinisikan sejarah tentang augmented reality dimulai dari tahun 1957-1962, ketikaseorang penemu yang bernama morton's seorang

72 | Alvebi Hopaliki; Yupianti; Juju Jumadi, Augmanted Reality Pengenalan Hewan Purbakala Animasi 3..... 
sinematografer, menemukandan memapatenkan sebuah simulator yang disebut sensorama dengan visual,getaran dan bau. Sensorama adalah sebuah mesin simulator yang dapatmenangkap visual, suara, getaran, dan bau.Yang hari ini dianggap multimedia.

Pada tahun 1966, ivan sutherland menemukan head-mounted display (hmd) yang dia klaim adalah, jendela ke dunia virtual yang merupakan perangkat layar yang dipakai di kepala atau sebagai bagian dari helm, yang memiliki tampilan kecil optik di depan salah satu atau setiap mata. Sebuah hmd khas memiliki salah satu atau dua layar kecil dengan lensa dan cermin semi transparan tertanam di helm, kacamata digunakan sebagai visor atau penangkap data.

Myron krueger menemukan videoplace yang memungkinkan pengguna untuk berinteraksi dengan objek virtual untuk pertama kalinya. Pada 1970-an pertengahan, myron krueger membentuk realitas buatan laboratorium disebut videoplace. Idenya dengan videoplace adalah penciptaan suatu realitas buatan yang dikelilingi para pengguna, dan menanggapi gerakan mereka dan tindakan, tanpa dibebani dengan menggunakan kacamata atau sarung tangan. Pada tahun 1989 jaron lanier memperkenalkan dan memanfaatkan virtual reality untuk bisnis pertama kali di dunia maya.

Kemudian pada tahun 1994 julie martin memanfaatkan augmented reality untuk produksi theatre. Pada tahun 1999, hirokazu kato, mengembangkanartoolkit suatu software library untuk membangun augmented reality yang dikembangkan oleh $\mathrm{dr}$ hirozaku kato dari universitas osaka jepang dan didukung oleh human interface technology (hit) laboratory university of washington dan hit lab. Nz university of cantertbury new zealand. Dan kemudian didemonstrasikan di siggraph.pada tahun 2009, saqoosha memperkenalkan flartoolkit yang merupakan perkembangan dari artoolkit.(putra, 2013:ii-6).

Augmented reality (ar) merupakan sebuah istilah untuk benda-benda nyata dan maya di lingkungan nyata, berjalan secara interaktif dalam waktu nyata, dan terdapat integrasi antar benda dalam tiga dimensi, yaitu benda maya terintegrasi dalam dunia nyata. Penggabungan benda nyata dan maya dimungkinkan dengan teknologi tampilan yang sesuai, interaktivitas dimungkinkan melalui perangkat-perangkat input tertentu, dan integrasi yang baik memerlukan penjejakan yang efektif. Selain menambahkan benda maya dalam lingkungan nyata, realitas tertambah juga berpotensi menghilangkan benda-benda yang sudah ada.Menambah sebuah lapisan gambar maya dimungkinkan untuk menghilangkan atau menyembunyikan lingkungan nyata dari pandangan pengguna.Misalnya, untuk menyembunyikan sebuah meja dalam lingkungan nyata, perlu digambarkan lapisan representasi tembok dan lantai kosong yang diletakkan di atas gambar meja nyata, sehingga menutupi meja nyata dari pandangan pengguna.

Pengaplikasian augmented reality memiliki daya tarik tersendiri karena keunikannya, mulai dari perorangan hingga tingkat perusahaan pun tertarik menggunakan aplikasi augmented reality, seperti perusahaan lego, general electrics, ikea, yang mengaplikasikan ar untuk mempromosikan produknya. Augmented reality ini juga dikembangkan oleh perusahan-perusahaan permainan konsol modern untuk menambah daya tarik permainan, diantaranya adalah perusahaan sony yang meluncurkan psp vita dengan fitur ar dalam permainannya. Tidak ketinggalan 
perusahaan pos di amerika serikat yaitu priority mail (united states postal service) pun menggunakan rar dalam salah satu produknya (adidrana dkk, 2013:1)

\section{LANDASAN TEORI}

\section{Pengertian media pembelajaran}

Media dalam prespektif pendidikan merupakan instrumen yang sangat strategis dalam ikut menentukan keberhasilan proses belajar mengajar. Sebab keberadaannya secara langsung dapat memberikan dinamika tersendiri terhadap peserta didik.

Kata media pembelajaran berasal dari bahasa latin "medius" yang secara harfiah berarti "tengah", perantara atau pengantar. Dalam bahasa arab, media perantara atau pengantar pesan dari pengirim kepada penerima pesan.

Gerlach dan ely mengatakan bahwa media apabila dipahami secara garis besar adalah manusia, materi, atau kejadian yang membangun kondisi yang membuat siswa mampu memperoleh pengetahuan, keterampilan, atau sikap.(putra, 2013:ii-1)

Dalam pengertian ini guru, buku teks, dan lingkungan sekolah merupakan media. Secara lebih khusus, pengertian media dalam proses belajar mengajar cenderung diartikan alat-alat grafis, photografis, atau elektronis untuk menangkap, memproses, dan menyusun kembali informasi visual dan verbal.

Maka dapat dikatakan bahwa media pembelajaran adalah segala sesuatu yang menyangkut software dan hardware yang dapat digunakan untuk menyampaikan isi materi ajar dari sumber belajar ke pembelajar (individu atau kelompok), yang dapat merangsang pikiran, perasaan,perhatian dan minat pebelajar sedemikian rupa sehingga proses belajar (di dalam/di luar kelas) menjadi lebih efektif.(putra 2013:ii-1).

\section{Pengertian Pattern Recognition (Pengenalan Pola)}

Pola adalah suatu entitas yang terdefinisi (mungkin secara samar) dan dapat diidentifikasi serta diberi nama. Pola bisa merupakan kumpulan hasil pengukuran atau pemantauan dan bisa dinyatakan dalam notasi vektor. Contoh : sidik jari, raut wajah, gelombang suara, tulisan tangan dan lain sebagainya. Dalam pengenalan pola data yang akan dikenali biasanya dalam bentuk citra atau gambar, akan tetapi ada pula yang berupa suara. Secara umum pengenalan pola (pattern recognition) adalah suatu ilmu untuk mengklasifikasikan atau menggambarkan sesuatu berdasarkan pengukuran kuantitatif fitur (ciri) atau sifat utama dari suatu obyek.Pengenalan pola (pattern recognition) merupakan teknik yang bertujuan untuk mengklasifikasikan citra yang telah diolah sebelumnya berdasarkan kesamaan atau kemiripan ciri yang dimilikinya. Bagian terpenting dari teknik pengenalan pola adalah bagaimana memperoleh informasi atau ciri penting yang terdapat dalam sinyal. (Ardiansyah, 2014:3)

\section{Vuforia}

Menurut Mario (2013) Vuforia merupakan software untuk Augmented Reality yang dikembangkan oleh Qualcomm, mengenai visi komputer yang berfokus pada pengenalan gambar. Vuforia mempunyai banyak fitur-fitur dan kemampuan, yang dapat membantu pengembangan untuk mewujudkan pemikiran tanpa batas secara teknikal. Dengan support untuk iOS, Android, dan Unity3D, platform Vuforia mendukung para pengebangan untuk membuat aplikasi yang dapat digunakan di hampir seluruh jenis smartphone dan tablet. 
Vuforia dikhususkan untuk pembuatan aplikasi mobile,maka dari itu inputnya adalah melalui kamerasmartphone dan outputnya adalah layar smartphone.Memang terlihat sedang merekam sesuatu, tapi memangbenar seperti itu. Perbedaannya adalah sistemmenganalisis object dunia nyata, bukan menyimpaninformasi-informasi gambar atau video.

Vuforia dapat mendeteksi beberapa jensi target, target yang digunakan disini adalah Image targets, merupakantarget yang bersifat image/gambar

\section{Unity 3D}

Menurut Rickman (2014) Unity Technology dibangun pada tahun 2014 oleh David Helgason, Nicholas Francis dan Joachim Ante. Game engine dibangun atas kepedulian mereka terhadap indie developer developer yang tidak bisa membeli game engine karena terlalu mahal. Fokus perusahaan ini adalah membuat sebuah perangkat lunak yang bisa digunakan oleh semua orang, khususnya untuk membangun sebuah game. (Akbar dkk, 2015:14)

\section{Blender}

Pada tahun 1988 Ton Roosendaal mendanai perusahaan yang bergerak dibidang animasi yang dinamakan NeoGeo. NeoGeo adalah berkembang pesat sehingga menjadi perusahaan animasi terbesar di Belanda dan salah satu perusahaan animasi terdepan di Eropa. Ton Roosendaal selain bertanggung jawab sebagai art director juga bertanggung jawabatas pengembangan software internal.

Pada tahun 1995 muncullah sebuah software yang pada akhirnya dinamakan Blender. Setelah diamati ternyata Blender memiliki potensi untuk digunakan oleh artis -artis diluar NeoGeo. Lalu pada tahun 1998 Ton mendirikan perusahaan yang bernama Not a Number (NaN) Untuk mengembangkan dan memasarkan Blender lebih jauh. Cita - cita $\mathrm{NaN}$ adalah untuk menciptakan sebuah software animasi 3D yang padat, cross platform yang gratis dan dapat digunakan oleh masyarakat computer yang umum.

\section{METODE PENELITIAN}

\section{Metode Analisis}

A. Rancangan Interface

[1] Rancangan Halaman AwalHalaman awal adalah sebuah tampilan awal atau pembuka pada suatu aplikasi atau interface, dalam penelitian ini rancangan halaman awal adalah sebagai berikut :

[2] Rancangan Halaman Ar Hewan

Rancangan ar hewan berisi button nama hewan purbakala, pada tampilan ar hewan terdapat sub kategori. Adapun rancangan halaman ar hewan dapat dilihat pada Gambar 3.6.

[3] Rancangan Halaman Deskripsi Ar Hewan

Rancangan deskripsi ar hewan merupakan informasi detail gambar dan keterangan secara detai dari hewan yang dipilih. Adapun rancangan halaman deskripsi ar hewan

[4] Rancangan Halaman Tentang

Rancangan halaman tentang berisi informasi tentang penulis dan penelitian ini, adapun rancangan halaman tentang

[5] Rancangan Halaman Petunjuk 
Pada halaman ini memberikan informasi bagaimana cara yang benar dalam penggunaan aplikasi ini agar aplikasi dapat berjalan dengan lancar. Adapun rancangan halaman petunjuk

[6] Rancangan Halaman Keluar

Rancangan halaman keluar merupakan konfirmasi keluar dari aplikasi, adapun rancangan halaman keluar

\section{B. Pengkodean}

Dalam aplikasi pengenalan hewan purbakala dengan augmented reality berbasis android, terbagi atas 3 bagian :

[1] library vuforia dalam pembuatan augmented reality ini digunakan sebagai pembuatan marker.

[2] Unity3D sebagai editor untuk menampung data dari vuforia dan koding interface.

[3] Untuk instruksi pemanggilan scene, menggunakan bahasa pemograman Csharp.

\section{Metode Pengujian}

Firebase Test Lab for Android memberikan infrastruktur berbasis cloud untuk menguji aplikasi Android. Dengan satu operasi, Anda bisa memulai pengujian aplikasi di berbagai macam perangkat dan konfigurasi perangkat. Hasil pengujian termasuk log, video, dan screenshot tersedia dalam project di Firebase console. Test Lab dapat mencoba aplikasi secara otomatis, untuk mencari tahu apakah terjadi error.

\section{HASIL DAN PEMBAHASAN}

\section{Pembahasan}

Hasil penelitian ini untuk membangun media pembelajaran hewan purbakala secara real time dengan menggunakan teknologi augmented reality. Setelah merancang dan membuat objek beserta pengkonfigurasian menjadi AR, dilakukan pembuatan tampilan dan proses Build Application.

Sehingga manfaat penelitian ini akan tercapai dengan baik dan benar, adapun manfaat penelitian adalah sebagai berikut :

[1] Menarik minat belajar siswa dalam pembelajaran hewan purbakala dan sejarah.

[2] Mempermudah dalam pembelajaran hewan-hewan prasejarah bagi para pelajar SMK Negeri 2 Empat Lawang.

[3] Membantu guru dalam menjelaskan dan memvisualisasikan kehidupan hewan purbakala

Tampilan menu utama mempunyai 4 menu, yaitu mulai, petunjuk, tentang, dan keluar. Adapun tampilan menu utama dapat dilihat pada Gambar 1.

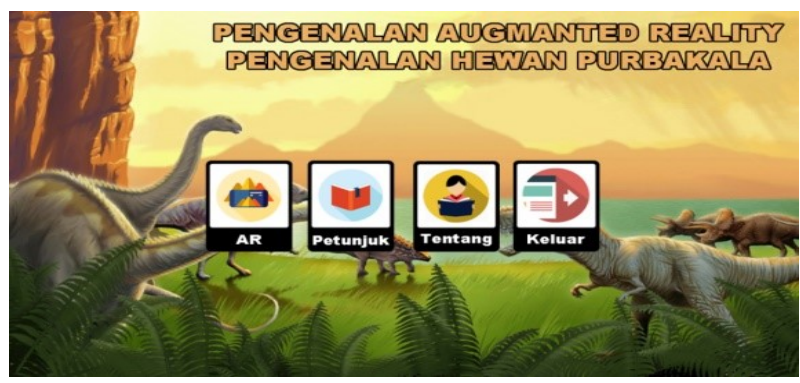

76 | Alvebi Hopaliki; Yupianti; Juju Jumadi, Augmanted Reality Pengenalan Hewan Purbakala Animasi 3..... 


\section{Gambar 1 Tampilan Menu Utama}

1. Tampilan Menu Ar

Tampilan menu ar hewan berisi button nama hewan purbakala, pada tampilan ar hewan terdapat sub kategori. Adapun tampilan halaman ar hewan dapat dilihat pada Gambar 2.

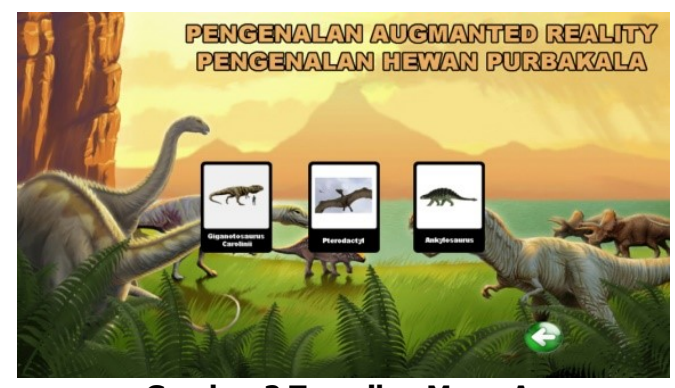

Gambar 2 Tampilan Menu Ar

2. Tampilan Deskripsi Hewan

Tampilan deskripsi ar hewan merupakan informasi detail gambar dan keterangan secara detai dari hewan yang dipilih. Adapun tampilan halaman deskripsi ar hewan dapat dilihat pada Gambar 3

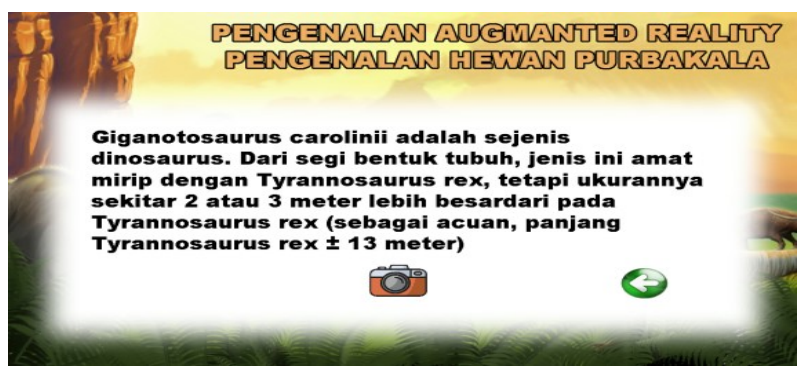

Gambar 3 Tampilan Deskripsi Ar Hewan

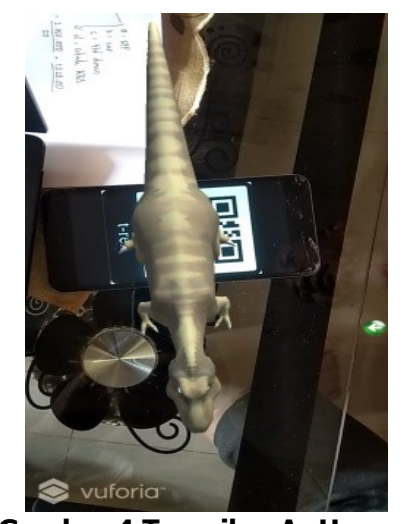

\section{Tampilan Menu Tentang}

Tampilan menu tentang merupakan informasi tentang augmanted reality dari aplikasi, adapun tampilan menu tentang dapat dilihat pada Gambar 5. 


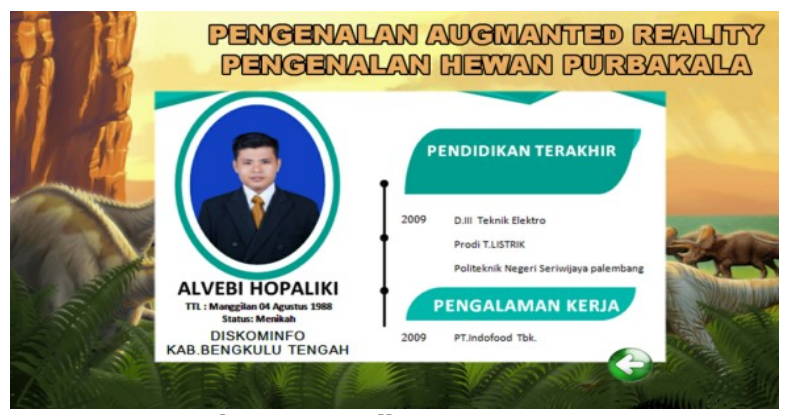

Gambar 5 Tampilan Menu Tentang

\section{Tampilan Menu Petunjuk}

Pada halaman ini memberikan informasi bagaimana cara yang benar dalam penggunaan aplikasi ini agar aplikasi dapat berjalan dengan lancar. Adapun tampilan halaman petunjuk dapat dilihat pada Gambar 6.

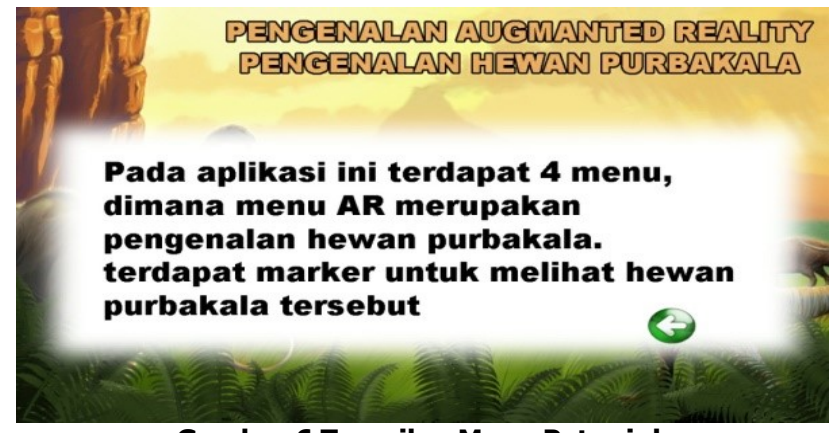

Gambar 6 Tampilan Menu Petunjuk

Pengujian Sistem dari hasil penelitian, maka pengujian sistem augmanted reality pengenalan hewan purbakala animasi 3 dimensi dengan pattern recognition berbasis android menggunakan google firebase dengan pengujian performa testlab. Adapun pengujian sistem dapat dilihat pada Gambar 3 dan Gambar 4.

\section{Pengujian Screenshoot}

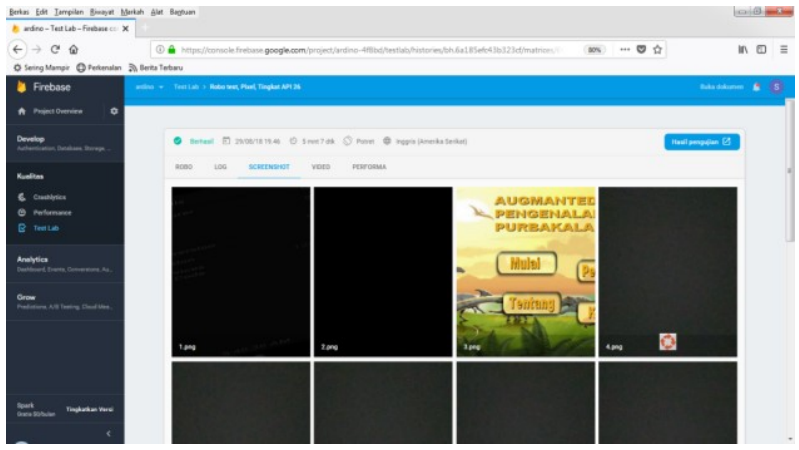

Gambar 7 Pengujian Testlab Screenshoot

78 | Alvebi Hopaliki; Yupianti; Juju Jumadi, Augmanted Reality Pengenalan Hewan Purbakala Animasi 3..... 


\section{GATOU RACA गOURNAL}

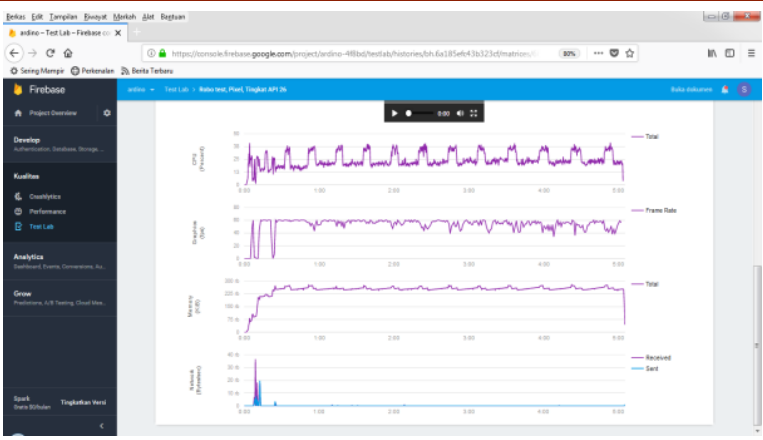

Gambar 8 Pengujian Testlab Screenshoot

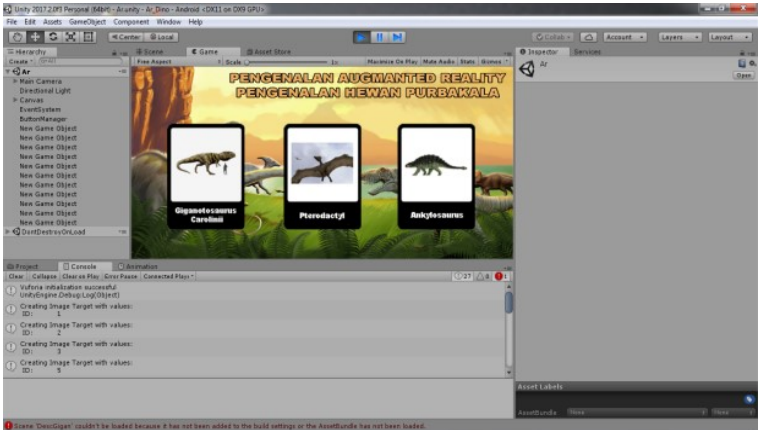

Gambar 9 Pengujian Pesan Kesalahan

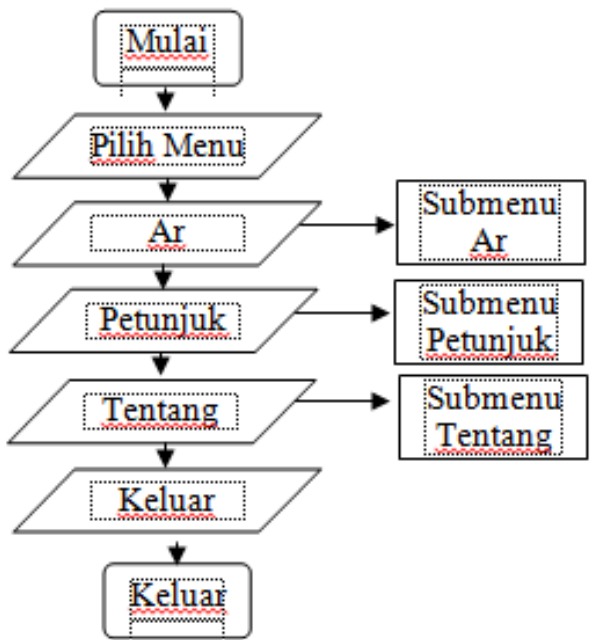

Gambar 10 Flowchart Aplikasi

Dari hasil penelitian, maka pengujian sistem augmanted reality pengenalan hewan purbakala animasi 3 dimensi dengan pattern recognition berbasis android menggunakan google firebase dengan pengujian performa testlab.Adapun pengujian sistem dapat dilihat pada Gambar 4.3 dan Gambar 4.4. 
2. Pengujian Screenshoot

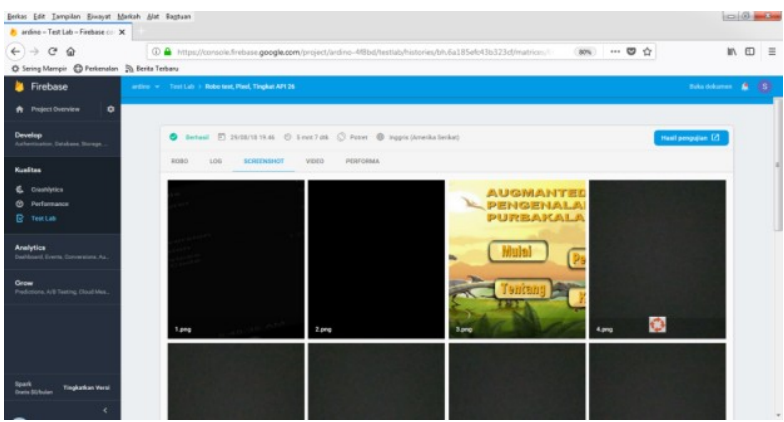

Gambar 11 Pengujian Testlab Screenshoot

3. Performa

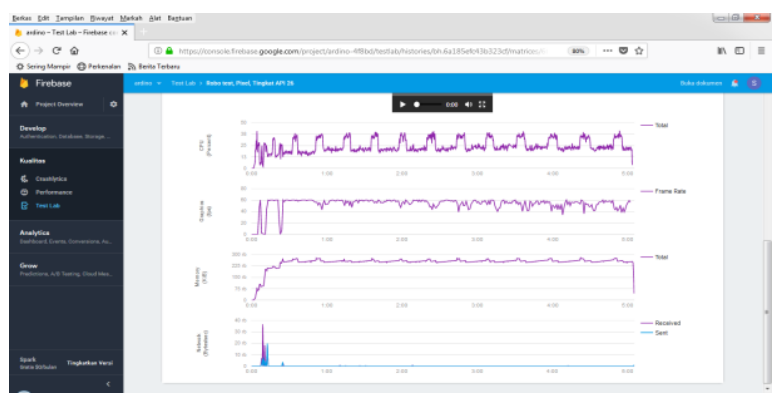

Gambar 12 Pengujian Testlab Screenshoot

4. Pesan Kesalahan

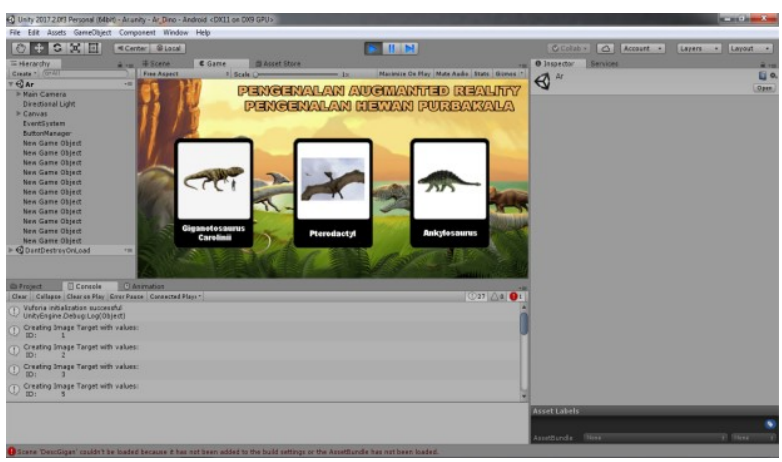

Gambar 13 Pengujian Pesan Kesalahan

80 | Alvebi Hopaliki; Yupianti; Juju Jumadi, Augmanted Reality Pengenalan Hewan Purbakala Animasi 3..... 


\section{KESIMPULAN DAN SARAN}

\section{Kesimpulan}

Dari hasil pengujian aplikasi augmanted reality pengenalan hewan purbakala animasi $3 d$ dengan pattern recognition berbasis android, dapat ditarik kesimpulan sebagai berikut

[1] Aplikasi ini dapat membangun media pembelajaran hewan purbakala secara real time dengan menggunakan teknologi augmented reality.

[2] Dapat digunakan untuk menambah ilmu pengetahuan dan sebagai bahan untuk pengembangan dan menerapkan aplikasi augmanted reality sehingga mempermudah dalam pembelajaran hewan-hewan prasejarah bagi para pelajar SMK Negeri 2 Empat Lawang.

[3] Membantu guru dalam menjelaskan dan memvisualisasikan kehidupan hewan purbakala namun terdapat kekurangannya yaitu tidak dapat menampilkan lingkungan hewan purbakala

[4] Aplikasi ini digunakan pada handphone OPPO dengan Ram 3 Gb terasa Lambat, disarankan menggunakan rang $4 \mathrm{~Gb}$

\section{DAFTAR PUSTAKA}

Ahira, Anne. 2012. Teknologi Informasi Berbasis Internet. PT. Elek Media Komputindo: Jakarta.

Dewanto, Wiwit. 2006. Membuat Aplikasi Database Berbasis Web, Penerbit PT. Elex Media Komputindo: Jakarta.

Jogiyanto, 2005, Sistem Teknologi Informasi. Andi Offset: Yogyakarta. 644 Halaman

Kadir, Abdul.2000. Pengenalan Sistem Informasi: Yogyakarta.

Kristianto, Hariyanto, 2003, Konsep Perancangan Database: 469 Halaman Yogyakarta: Andi Offset. 455 Halaman

Kasman, 2013. Sistem Pakar Untuk Diagnosa Gizi Berbasis Android. Jurnal Jurusan Teknik Informatika STMIK PalComTech: Palembang

Proboyekti, Umi. 2011, Rekayasa Website Dalam Teknologi Informasi. Yogyakarta: Andi Offset.

Pender, 2002. Pengenalan Umum Unified Modeling Language. Andi Offset: Yogyakarta Setiawan, Andi. 2007.Panduan Lengkap Adobe Dreamweaver, CV. Andi: Yogyakarta. 
82 | Alvebi Hopaliki; Yupianti; Juju Jumadi, Augmanted Reality Pengenalan Hewan Purbakala Animasi 3..... 